Author version: Estuar. Coast., vol.37(6); 2014; 1415-1431

\title{
Impact of 'Chitra' oil spill on tidal pool macrobenthic communities of a tropical rocky shore (Mumbai, India)
}

\author{
Soniya Sukumaran*, Jyoti Mulik, M. A. Rokade and Archana Kamble \\ CSIR-National Institute of Oceanography, Regional Centre Andheri (W), Mumbai 400 053, India
}

\begin{abstract}
A collision between the ships, MSC Chitra and MV Khalijia 3 in the mouth region of Mumbai Harbour led to a leakage of around $800 \mathrm{t}$ of fuel oil in August 2010, affecting rocky intertidal region of Colaba. To evaluate the impact of this catastrophic event on the resident biota, a 15-month long sampling programme was initiated in the oil affected area immediately after the spill. Petroleum hydrocarbons in water and sediment organic carbon values were high just after the oil spill but subsequently decreased in the following months. In total, 70 macrobenthic taxa were identified. Univariate diversity indices indicated that while the ecological status of the site, albeit briefly, was affected during August 2010, a healthy environment prevailed subsequently. Cluster and MDS analyses distinctly segregated the oil impacted monsoon months from the other sampling months. BIOENV analyses indicated that petroleum hydrocarbons and organic carbon were the anthropogenic parameters influencing macrobenthic community structure. BOPA index was used to evaluate ecological quality of the study area as the index is sensitive to oil pollution. Low BOPA values throughout the study period indicated that the environment was good with few opportunistic species. Comparison with past data revealed that the oil spill did not have long term deleterious effects on the macrobenthic species diversity of this rocky beach and reasons thereof are discussed.
\end{abstract}

\footnotetext{
* Corresponding author. Tel: +91 222635 9605; Fax: +91 2226364627

E-mail address: soniya@nio.org (Soniya Sukumaran)
}

Keywords: oil spill; rocky shore; tropical; benthos; tidal pools 


\section{Introduction}

Notwithstanding the tremendous strides made in ship technology and international regulatory initiatives, oil spills keep occurring more so in the developing world (Islam and Tanaka 2004; Sivadas et al. 2008) especially on shores along major shipping routes (Thompson et al. 2002). Indian west coast, in particular, is vulnerably exposed to oil accidentally or clandestinely released in the Arabian Sea largely during the southwest monsoon months (June-September) when the alongshore surface current develops an easterly shoreward component (Gouveia and Kurup 1977). Mumbai, a major commercial hub, is located on the western coast of India and has been vulnerable to oil pollution due to the presence of a harbour and major oil terminal. A collision occurred between the ships, MSC Chitra and MV Khalijia 3 in the mouth region of Mumbai Harbour (18 $51^{\prime} 99^{\prime} N$ 72 $42^{\circ} 03^{\prime}$ E) on 7 August 2010. Subsequently, the rough sea conditions resulted in the drifting of MSC Chitra which then ran aground on the Prongs reef off Colaba (Fig. 1) leading to a leakage of around $800 \mathrm{t}$ of fuel oil (NIO 2011). Despite the efforts of the Indian Coast Guard to contain the spill, it quickly covered vast areas in the Mumbai Bay and sites along the open coast south of the Bay aided by a combination of strong southwest winds and monsoonal onshore currents. The oil spill covered an area of $20 \mathrm{~km}^{2}$ up to Vashi in the inner Mumbai Bay. An initial survey conducted by the National Institute of Oceanography indicated that concentration of oil in water at some subtidal stations in the Bay reached as high as $16902 \mu \mathrm{g} \mathrm{l}^{-1}$. These values however reduced to lower levels within a short period after the oil spill (NIO 2011).

Due to its proximity with the accident site, Colaba coast was one of the earliest segments to be significantly coated by the oil spill (Fig. 1). Colaba, situated on the southern most tip of Mumbai, has a rocky beach which supports diverse marine biota including well-developed corals. Despite being a part of Mumbai Metropolitan Region (MMR) which is the largest coastal urban settlement in India, the biodiversity of the Colaba zone is preserved primarily due to its non-accessibility owing to its unique location (Fig. 1). Previous biological studies in the rocky intertidal of Colaba include descriptions of macroalgae (Dhargalkar and Komarpant 2003) and epifauna (Datta et al. 2010). Both accounts indicate the diverse nature of ecological communities of the area.

Marine macrobenthos has been widely employed to study the impact of environmental perturbations including oil spills (Guidetti et al. 2000), as they are the species rich, ubiquitous group consisting of both sensitive and hardy organisms with relatively long life span. Being predominantly sessile, they are exposed to sediment contamination and have varied response to stress depending on the 
species hardiness (Gesteira and Dauvin 2005). While many ecological health status indicators and indices based on variations in macrobenthic community have been proposed (Dauvin et al. 2010), the BOPA index (Benthic Opportunistic Polychaetes Amphipods Index) is widely used for determining the impact of oil spill on benthic communities in coastal waters (Dauvin and Ruellet 2007; Joydas et al. 2012).

Given that intertidal zones are under greatest threat from oil pollution, studies galore have been conducted on the adverse effects of oil spills on intertidal macrobenthic communities in temperate latitudes (Hir and Hily 2002; Yamamoto et al. 2003; Junoy et al. 2005; Lv et al. 2011). Reported impacts of an oil spill on rocky intertidal macrofauna include smothering of organisms by oil (Shriadah 1998), disruption of settlement of juveniles (Nelson 1982), change in recruitment, growth and community structure, reduction in species diversity (Hir and Hily 2002; Crowe et al. 2000) and annihilation of sensitive species (Yamamoto et al. 2003; Stevens et al. 2012). However only limited information on the immediate to medium term effect of an oil spill on macrobenthos of rocky intertidal area in the tropics is available (but see Jones et al. 1998; Edgar et al. 2003; Stevens et al. 2012). Also few oil spill related impact assessment studies on macrobenthos (Ingole et al. 2006; Sivadas et al. 2008) are available for the $5700 \mathrm{~km}$ long Indian coastline. Biological diversity is higher in tropical zones (Wafar et al. 2011) and therefore the impact of oil pollution on such regions may be higher as compared to other areas (NAS 1985; Agard et al. 1993).

The Chitra oil spill presents an opportunity to study the impact of oil pollution on the benthic ecology of sedimented intertidal rocky pools in a tropical clime. The objective of the present investigation was to evaluate the impact of the oil spill on the resident macrobenthos of a relatively clean rocky beach subsequent to the oil spill using a suite of univariate and multivariate analyses. As impacts of oil spill may manifest over a few months after the episode (Stevens et al. 2012) and to account for seasonal impact, monitoring of the selected site was conducted for over 15 months. Also we compare the present macrofaunal data with that obtained in the same study area prior to the oil spill (Datta et al. 2010) to comprehend the extent of ecological damage caused by the spill.

\section{Material and Methods}

\subsection{Study site}

Colaba is located near the southern most tip of Mumbai. The study area $\left(18^{\circ} 54^{\prime} 19.6^{\prime \prime} \mathrm{N}\right.$ $\left.72^{\circ} 48^{\prime} 12.2^{\prime \prime} \mathrm{E}\right)$ is located in a rocky intertidal area known as 'Prongs reef' (Fig. 1). The irregular rocky 
area of $0.5 \mathrm{~km}^{2}$ which gently slopes towards the sea entraps several water pools during ebb. These tidal pools with sandy bottoms provide an ideal environment for marine organisms. The climate of the study area is typical of that of the central west coast of India with plentiful and regular rainfall occurring during June-September, oppressive summer (March-May) and a mild winter (December-February). General coastal circulation off Colaba is dominated by the annual cycle of monsoon winds. Near shore waters of Colaba are subjected mainly to semi-diurnal tides and there exists an asymmetry in both period and range. The flood tidal front advances in a northeasterly direction and ebbs towards the southwest. Mean tide ranges at Mumbai are 1.6 and 3.9 m during neap and spring respectively.

\subsection{Sampling}

The Colaba site was entirely covered by oil in August 2010. The study site is unique as it is the only coralline intertidal area along the Mumbai coast. Being a restricted area there is only limited access to the shore, therefore human interference is practically nil. Other rocky shores of Mumbai which were not impacted (North Mumbai) are not coralline and are heavily frequented by people and therefore polluted to various levels. Therefore no reference station could be established. Sampling at Colaba commenced on 13 August 2010 by which time the spill had covered the upper and middle intertidal zone to a significant extent while the lower intertidal zones had little or no traces of oil contamination. Upper intertidal zone was covered by concrete tripods for protection against sea erosion while the lower intertidal area was inaccessible due to the strong monsoonal waves. Sampling locations preferred were the sedimented tidal pools in the heavily oiled middle intertidal areas as it was observed during the initial sampling (August 2010) that oil was most prevalent in these areas. For macrobenthic analyses, monthly, four sediment samples were collected from four different rocky tidal pools situated within a radius $\sim 300 \mathrm{~m}$. All rocky pools were shallow (water depth $\sim 10-20 \mathrm{~cm}$ ) with sandy sediments (thickness $\sim 5-10 \mathrm{~cm}$ ). The co-ordinates were fixed using a hand held GPS (Garmin) and the sediment samples were collected using quadrats $(1 \times 1 \mathrm{~m})$. Sampling was conducted at these fixed locations from August 2010 to October 2011 during spring low tides.

Sediment samples were also collected separately to analyze sediment texture, organic carbon $\left(\mathrm{C}_{\text {org }}\right)$ and total petroleum hydrocarbons (PHc-sediment). Water samples were collected for analyses of physico-chemical parameters like temperature, $\mathrm{pH}$, suspended solids (SS), dissolved oxygen (DO), reactive phosphate phosphorous $\left(\mathrm{PO}_{4}{ }^{3-}-\mathrm{P}\right)$, nitrate-nitrogen $\left(\mathrm{NO}_{3}{ }^{-}-\mathrm{N}\right)$, ammonia-nitrogen $\left(\mathrm{NH}_{4}{ }^{+}-\mathrm{N}\right)$ and total petroleum hydrocarbons (PHc-water). Samples for the aforementioned hydrosedimentological 
parameters were collected only from the middle two pools (representative pools) due to logistical constraints.

\subsection{Laboratory analyses}

Sediments collected for macrobenthic analyses were sieved through a $0.5 \mathrm{~mm}$ mesh sieve and fixed in 5\% formalin mixed with Rose Bengal. The benthic organisms were then sorted to lowest possible taxa (usually species), enumerated and expressed as ind. $\mathrm{m}^{-2}$. Water temperature was recorded using a mercury thermometer with an accuracy of $\pm 0.1^{\circ} \mathrm{C}$. $\mathrm{pH}$ was measured on a Cyber Scan (Model pH 510) pH meter. Salinity, SS, DO and nutrients were analyzed using standard methods (Grasshoff et al. 1999). PHc in sediment and water was measured with a fluorescence spectrophotometer (LS 3B Perkin Elmer) (IOC-UNESCO 1982; 1984). C org was analyzed by titration method (Walkey and Black 1934) and sediment texture by combined sieving and pipette method (Buchanan 1984).

\subsection{Statistical analyses}

Species number and abundance data from all four replicates were pooled for each month for statistical analyses. Univariate and multivariate analyses of macrobenthic data were carried out using the statistical software, PRIMER v6 (Clark and Gorley 2006). To assess the environmental quality the univariate diversity indices calculated were Shannon-Wiener diversity index, $H^{\prime}\left(\log _{2}\right)$; Margalef's index, $d$; and Pielou's evenness index, $J$ '. One-way analysis of similarity (ANOSIM, randomization/permutation procedure) was carried out to assess significant differences in benthic invertebrate assemblages between seasons which were defined as follows: August-September 2010 (Monsoon 2010), October 2010-February 2011 (Postmonsoon), March-May 2011 (Premonsoon) and June-October 2011 (Monsoon 2011). The R-statistic value was used to evaluate the extent of any significant difference.

The square root transformed macrobenthic abundance data was used to construct a similarity matrix using Bray-Curtis similarities. This similarity matrix was then subjected to cluster analyses using the group average method and ordination by non-metric Multi-Dimensional Scaling (nMDS). A similarity profile (SIMPROF) test was conducted to detect the significantly different month groups using the default of 1000 permutations for mean similarity profile and 999 permutations for the simulated profile with the significance level of 0.05 . Similarity of percentages analysis (SIMPER) was carried out to identify the major species which typified groups and those most responsible for the discrimination between groups. 
Pearson correlation coefficient $(r)$ was estimated between macrobenthic taxa, diversity indices and environmental parameters, using the software Statistica 7. Non-parametric matrix correlation using BIOENV was carried out to test relationships of macrobenthic community composition with all measured environmental variables. The results indicate the suite of environmental variables that correlate best with changes in relative abundance of the macrofaunal community.

In this study, the Benthic Opportunistic Polychaetes Amphipods Index (BOPA) (Dauvin and Ruellet 2007) was applied to study the potential impact of oil spill on the macrobenthos of the study area. This index compares percentage ratios of opportunistic polychaetes and amphipods and is low in good environs and high in stressed zones. The five EcoQ (ECOlogical Quality Status) classes, the pollution classification (in parentheses) and corresponding BOPA ranges as per De-la-Ossa-Carretero and Dauvin (2010) are as follows:

$$
\begin{array}{lc}
\text { High (unpolluted sites) } & 0.00000 \leq \mathrm{BOPA} \leq 0.02452 \\
\text { Good (slightly polluted) } & 0.02452 \leq \mathrm{BOPA} \leq 0.13002 \\
\text { Moderate (moderately polluted) } & 0.13002 \leq \mathrm{BOPA} \leq 0.19884 \\
\text { Poor (heavily polluted) } & 0.19884 \leq \mathrm{BOPA} \leq 0.25512 \\
\text { Bad (extremely polluted) } & 0.25512 \leq \mathrm{BOPA} \leq 0.30103
\end{array}
$$

\section{Results}

\subsection{Abiotic conditions}

Temporal variability in hydro-sedimentological parameters measured during the study is displayed in Fig. 2. Water temperature ranged from $24.3^{\circ} \mathrm{C}$ (January-2011) to $30.2^{\circ} \mathrm{C}$ (May-2011) averaging $28.2^{\circ} \mathrm{C}$ (Fig. 2A). Water pH remained low (7.4-8.0) during August 2010-January 2011 and increased to 7.9-8.4 during February-October 2011 (Fig. 2B). SS were in the range (13-395 $\mathrm{mg} \mathrm{l}^{-1}$; av $68 \pm 99 \mathrm{mg} \mathrm{l}^{-1}$ ) expected for the coastal waters and largely derived from the tidal dispersion of fine grained bed material in the water column (Fig. 2C). Salinity of the study area was mainly influenced by the land drainage during monsoon as indicated by the wide fluctuations in salinity (19.3-35.4; av 30.8 \pm 5.4 ). High premonsoon near shore salinity (35.4) decreased considerably (19.3) under the influence of monsoonal runoff during July-August followed by subsequent increase (35.2) due to the withdrawal of monsoon (Fig. 2D). The range of DO indicated that the overlying waters were well 
oxygenated (4.7-11.9 $\mathrm{mg} \mathrm{l}^{-1}$; av 7.5 $\left.\pm 2.1 \mathrm{mg} \mathrm{l}^{-1}\right)$ with higher values during October (2010 and 2011) (Fig. 2E).

$\mathrm{PO}_{4}{ }^{3-}-\mathrm{P}$, and $\mathrm{NH}_{4}{ }^{+}-\mathrm{N}$ values throughout the study period (Figs. $2 \mathrm{~F}$ and $2 \mathrm{H}$ ) indicated that the area was influenced by pollutants of urbanization which was expected considering the location (Fig. 1). Higher values of $\mathrm{NO}_{3}^{-}-\mathrm{N}$ were observed during monsoon months (i.e. August 2010 and June 2011) probably due to land run off during the season. Another high value of $\mathrm{NO}_{3}{ }^{-}-\mathrm{N}$ was detected in December 2010 (Fig 2G). PHc-water values were high in the aftermath of the oil spill (1825.4 $\mu \mathrm{g} \mathrm{1^{-1 }}$ in August 2010) but subsequently decreased in the following months (Fig. 2I).

PHc-sediment values ranged widely (5.6 - $311.3 \mu \mathrm{g} \mathrm{g}^{-1}$ wet wt.; av $45.3 \pm 77.2 \mu \mathrm{g} \mathrm{g}^{-1}$ wet wt.) indicating that the accumulation in the intertidal surface sediment of the rocky pools was patchy and erratic (Fig. 2J). $\mathrm{C}_{\text {org }}$ was high immediately after the spill (2.3\%) and indicated a decreasing trend during subsequent series of sampling (Fig. 2K). Sediment in the study area was predominantly sandy (86.4-

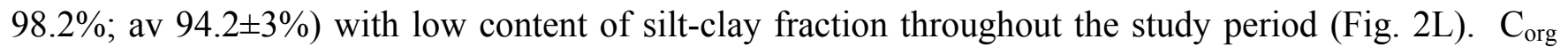
was positively correlated with PHc-water $(r=0.84 ; p<0.001)$ while PHc-sediment was negatively influenced by sand $\%(r=-0.84 ; p<0.001)$.

\subsection{Macrobenthic community}

From the 60 macrobenthic samples that were analysed during the study, 70 macrobenthic taxa were recorded (Appendix 1). Macrobenthic abundance ranged from 407 ind. $\mathrm{m}^{-2}$ (August 2010) to 3731 ind. $\mathrm{m}^{-2}$ (February 2011) and averaged $1331 \pm 925$ ind. $\mathrm{m}^{-2}$ (Fig. 3A). Polychaetes (44\%), amphipods $(30 \%)$ and gastropods (14\%) were the major groups accounting for $88 \%$ of the macrobenthic abundance and were present during all sampling months. Individually, other groups comprised $<3 \%$ of the macrobenthic population and were present sporadically throughout the sampling period.

With 34 species, polychaetes were the most diverse taxon. Scoloplos uniramus (39.8\%), Capitellidae sp. (22.2\%) and Prionospio sp. (8.6\%) were the dominant polychaetes. S. uniramus was present during all months except November 2010. Amphipods were mostly comprised of members of Melitidae (56.9\%) and Gammaridae (39.3\%) families. Gastropoda included 14 species and was majorly represented by Nerita oryzarum (39.0\%) and Nerita sp (27.3\%). N. oryzarum was all pervasive during the sampling period except for May 2011. Univariate indices like Species richness (d) was highest during February 2011 (3.4) and lowest during August 2010 (1.5) (Fig. 3B) while Pielou's evenness index $\left(J^{\prime}\right)$ was $>0.6$ during all 15 months (Fig. 3C). Shannon-Wiener index, $H^{\prime}\left(\log _{2}\right)$ ranged from 2.6 
(May 2011) to 3.7 (August 2011) (Fig. 3D). Apart from August 2010 and May 2011 all months showed $H^{\prime} \geq 3$.

One-way ANOSIM demonstrated significant differences between the macrobenthic fauna of different seasons (Global $\mathrm{R}=0.733 ; \mathrm{p}<0.001)$. Cluster analysis based on square root transformed macrobenthic abundance data clearly defined (as confirmed by SIMPROF test) three statistically distinct clusters (Fig. 4). Group a consisted of oil impacted monsoon months of 2010 (August-September 2010), Group $b$ comprised of postmonsoon months (October 2010-February 2011) while Group $c$ was constituted by the premonsoon and monsoon months of 2011 (March 2011-October 2011). The distinction between benthic assemblages of premonsoon and monsoon 2011 was not significant as per SIMPROF ( $p=0.05$ ) (Fig. 4). The three distinct cluster groups were clearly reproduced in the multi dimensional scale (MDS) plot in a cyclical mode indicating temporal variability (Fig. 5). Stress value of 0.14 implied acceptable ordination. The ordination also indicated that oil affected monsoon months (August-September 2010) had distinctly different macrobenthic community structure from other months (including that of monsoon 2011).

SIMPER analyses indicated that the similarity of Group a (37\%) was contributed largely by gammarids and Nerita oryzarum while Group $b$ similarity (48\%) was mainly due to amphipods belonging to Gammaridae and Melitidae. Average Bray-Curtis similarity of Group c (54\%) was contributed chiefly by $S$. uniramus, gammarids and melitids. Average dissimilarity between the three different groups and the discriminating species with respective contribution to the cumulative differences are given in Table 1. Thus the major discriminating taxa between the oil spill affected monsoon months (Group $a$ ) and the postmonsoon months (Group b) (av dissimilarity=66\%) were Melitidae, S. uniramus, Isopoda and Capitellidae. Distinction between Groups $a$ and $c$ (av dissimilarity $=68 \%$ ) was mainly due to Melitidae, Prionospio sp., Isopoda, S. uniramus and Nerita sp. Capitellidae, S. uniramus, Anomura and Melitidae were the major contributors of the dissimilarity of Groups $b$ and $c$ (av dissimilarity=59.8\%). The relative abundances of the discriminating taxa between the three different groups are given in Table 3 which indicated that the abundance of Melitidae had increased in the post spill period.

August 2010 (oil impacted monsoon month) had lower diversity (10 taxa) and average abundance (407 ind. $\mathrm{m}^{-2}$ ) as compared to August 2011 which had 19 taxa and average abundance of 488 ind. $\mathrm{m}^{-2}$. The groups which were previously absent in August 2010 but present during August 2011 were 
cirratulids, spionids, syllids, capitellids, bivalves, ophiuroids, eunicids, saccocirrids, molluscs, polyclads, melitids and brachyurans (Appendix 1). The most dominant polychaete, Scoloplos uniramus was relatively more abundant (20.5\%) during August 2011 than August 2010 (10.8\%).

\subsection{Environment-assemblage interactions}

Pearson correlation analyses of macrobenthic univariate indices with measured abiotic parameters showed that water temperature was negatively correlated with total macrobenthic abundance $(r=-0.70 ; p<0.01)$ while salinity negatively influenced Evenness index $J^{\prime}(r=-0.70 ; p<0.01)$. Species richness $d$ was negatively correlated with PHc-water $(r=-0.56 ; p<0.05)$. It is quite possible that the macrobenthic community structure was influenced by a suite of abiotic parameters rather than a single factor for which BIOENV analyses was undertaken. Results presented in Table 2 indicated that the combination of 5 variables viz. $\mathrm{C}_{\text {org }}$, PHc-water, water temperature, $\mathrm{SS}$ and silt gave the best correlation $(\rho=0.62)$. Among the three groups of sampling months formed by cluster and MDS ordination, Group $a$ (oil impacted monsoon season) was observed to have higher levels of $\mathrm{C}_{\text {org }}$, PHc-water, SS and water temperature, lower values of silt $\%$, species richness and diversity as compared to other groups (Table $3)$.

\subsection{Impact assessment of macrobenthos health status}

The health status of intertidal macrobenthos of Colaba during and subsequent to the oil spill was assessed by employing the BOPA index. The opportunistic species of the study area were Aonides sp., Boccardia polybranchia, Prionospio sexoculata, Prionospio sp., Prionospio cirrobranchiata, Spiophanes bombyx (all Spionidae); Capitellidae; Cauleriella sp., Cirratulus cirratus, Cirratulus sp., Tharyx marioni, Tharyx sp. (all Cirratulidae). Low BOPA values (Fig 6) indicated that the ecological status of the study area was 'high' during and immediately after the oil spill (August-November 2010). Thereafter an increase in BOPA values was detected resulting in a shift of the ecological status from 'high' to 'good' during rest of sampling period except during March and May 2011 when 'high' values of BOPA were indicated. It was also observed that amphipods were present in appreciable relative densities (12-50\%) during the 15 months of study.

\section{Discussion}

Visual inspection during the initial sampling (August 2010) indicated that large part of intertidal span was swathed by heavy fuel oil. While the oiling on the rocky shore at the study area was most 
severe immediately after the landfall of the oil slick, intertidal organisms like crabs and gastropods were found alive and active though many were smeared with oil. During the next sampling (September 2010), although the protective tripods on the upper zone and the rocky substratum were found to be free from oil coating, some of the tidal pools were seen with a thin film of oil. Thereafter oil was not sighted in areas previously coated with oil during subsequent monitoring.

Unlike the open ocean, even uncontaminated coastal waters are subject to significant short-time natural fluctuations due to variations in tide and seasons. For coastal and inshore areas of Mumbai that receive a large spectrum of wastes, such variations can be high for some water quality parameters. Values of water parameters like temperature and DO in the current study were in agreement with previous studies (Gupta et al. 2009; Kamble and Vijay 2011). Nutrients like $\mathrm{NH}_{4}{ }^{+}-\mathrm{N}$ and of $\mathrm{NO}_{3}{ }^{-}-\mathrm{N}$ were higher than earlier reported values at Colaba (Dhargalkar et al. 2001) indicating the influence of land based sources and nearby wastewater releases considering the proximity of the study area to highly urbanized zones.

Past studies (Ingole et al. 1995) have indicated average PHc-water concentrations in the intertidal segments of Colaba to be $19.7 \mu \mathrm{g}^{-1}$. Chouksey et al. (2004) have suggested $2.8 \mu \mathrm{g} 1^{-1}$ as baseline value for PHc-water for evaluating perturbations in the west coast of India due to anthropogenic releases other than traffic of fishing vessels and ships. Hence it is safe to assume that the oil spill resulted in the elevation of petroleum hydrocarbons concentrations in intertidal seawater of the study area during August 2010 (1825.4 $\mathrm{gg} \mathrm{l}^{-1}$ ). The ensuing decrease in PHc-water values in the months after August 2010 indicated that much of the PHc due to the oil spill was removed from the area aided by the strong monsoonal wave conditions of the sea. Further spikes in PHc-water values seen from December 2010 onwards are within the range expected in the coastal water of Mumbai in the absence of bulk release as per latest available data (2.3 to $72.4 \mu_{\mathrm{g}}{ }^{-1}$; NIO 2011). Also, proximity to Mumbai port exposes the waters in the study area to some degree of oil pollution from shipping activities (Datta et al. 2010). Somewhat similar trends were noticed by Lopes et al. (1997) while studying the effects of a heavy crude oil spill on macrobenthos of rocky shore along Sáo Paulo coast in Brazil. They found that the initial high levels of petroleum aromatic hydrocarbons (PAHs) in the water samples had declined in the following days which they attributed to evaporation and weathering process aided by wind, waves and temperature. 
The baseline concentration of PHc-sediment is expected to be around $3.0 \mu \mathrm{g} / \mathrm{g}$ (dry wt) or 1.5 $\mu \mathrm{g} / \mathrm{g}$ (wet wt. based on moisture content 50\%) in the sediment of the open shore areas of the north-west coast of India (Chouksey et al. 2004). Present PHc-sediment values were erratic (Fig. 2J) with higher values in November 2010. Irregular variation of PHc-sediment after an oil spill can occur mainly because of the insoluble nature of petroleum. When weathered oil sinks it may not be uniformly distributed on the bed and distribution is generally patchy. For the same reason the concentrations of PHc in water and sediment collected during a sampling event may not hold any relationship. Moreover, the weathered oil may be transferred to sediment as lumps which further complicate its distribution. Thus, the concentration of PHc-sediment would depend on lumps or oil captured in the sample. Further, the intertidal and near shore surface sediment is agitated by waves and even transported elsewhere and though the sampling may be done at the same site periodically, the sediment in the sample may not be identical to that sampled previously.

Macrofaunal abundance was highest during postmonsoon which is in agreement with previous studies conducted on west coast of India (Sivadas et al. 2011, Mandal and Harkantra 2013). Macrobenthic density was lowest during August 2010 and August 2011. Impoverishment of benthic fauna during south-west monsoon is a general trend seen in the beaches of west coast of India (Ansari and Ingole 2002). Lowest values of $H^{\prime}$ were observed during May $2011\left(H^{\prime}=2.6\right)$ and August 2010 $\left(H^{\prime}=2.8\right)$. During the other months, $H^{\prime}$ values were between 3 and 4 . Within the Water Framework Directive (WFD), the ecological quality is considered as "High" if $H$ '>4, "Good" if $3<H$ ' $\leq 4$, "Moderate" if $2<H^{\prime} \leq 3$, "Poor" if $1<H^{\prime} \leq 2$ and "Bad" if $H^{\prime} \leq 1$ (Vincent et al., 2002; Labrune et al., 2006). By this measure, it can be assumed that ecological status of the site, albeit briefly, was affected during August 2010. Conversely, $H^{\prime}$ was highest during August 2011 (3.7). Considering that the impact of rainfall was similar during August 2010 and August 2011 (as per salinity values), it appears that the low diversity values during the former period were largely due to the impact of spill. A low $H^{\prime}$ 'value during May 2011 (peak summer) was probably resultant of the high temperatures prevalent during this period. High evenness values (0.67-0.87) throughout the sampling period ruled out dominance by any opportunistic species as is commonly observed after many oil spills (Gesteira and Dauvin 2000; 2005; Kingston 2002) and were indicative of balanced benthic assemblages (Díaz-Castaneda and Harris 2004).

Reduction in macrobenthic species numbers and diversity due to oil spill have been reported in many oil spill impact assessment studies (Hir and Hily 2002; Zenetos et al. 2004; Stevens et al. 2012). Pre-spill status of macrobenthos in Colaba intertidal zone is limited to a solitary study conducted by 
Datta et al. (2010) from December 2006 to November 2007. As against the 48 macrobenthic taxa that were reported during 2006-2007, higher numbers of macrobenthic groups (70 taxa) were identified from our study. Also the range of $H^{\prime}$ during current study (2.6-3.7) was higher than that of 2006-2007 (2.12.9). Therefore this comparison may suggest that the oil spill did not have long term deleterious effects on the macrobenthic species diversity. Previous post-spill studies on intertidal rocky shores have reported virtual elimination of all species immediately after oil spill (Jones et al. 1998; Stevens et al. 2012). However, in our study, though abundance and diversity was less, live animals were noticed during August 2010. No detectable impacts on the intertidal invertebrate organisms of Galapagos in the aftermath of the Jessica oil spill were observed by Edgar et al. (2003). This finds resonance with the scenario that existed in our study area once the intertidal terrain was washed of the traces of oil under the onslaught of heavy monsoonal waves.

Among the 70 macrobenthic taxa identified, S. uniramus was the most abundant and omnipresent species (Appendix 1). While examining petroleum induced stress conditions of Todos os Santos bay in Brazil, Peso-Aguiar et al. (2000) have noted Scoloplos sp. to be intolerant to oil-impacted areas. Therefore the relatively abundant presence of $S$. uniramus after the oil impacted monsoon season shows that the environment was conducive for proliferation of sensitive species. Amphipods are particularly sensitive crustaceans which have been reported to be obliterated after an oil spill and hence often used to evaluate impact of oil spills on macrobenthic communities (Dauvin and Ruellet 2007; Nikitik and Robinson 2003). Large scale amphipod mortalities in the aftermath of oil spills have been reported in many other studies (Gesteira and Dauvin 2000; Hir and Hily 2002; Gesteira and Dauvin 2005). In the study area at Colaba, lowest number of amphipods was present during August 2010 (oil spill period), thereafter which the abundances largely showed an increasing trend (Appendix 1) during subsequent sampling months. This indicated that the area was favorable for this sensitive group to flourish during the post spill period. Similar increase in amphipod abundances following the Prestige oil spill has been reported by Junoy et al. (2005). In the present study, BOPA index was used to evaluate ecological quality of the study area as the index is sensitive to oil pollution and is considered appropriate to study temporal changes in benthic communities (Dauvin and Ruellet 2007). BOPA is based on the premise that an oil spill generally results in high mortalities of amphipods followed by proliferation of opportunistic polychaetes. Low BOPA values (Fig. 6) throughout the study period indicated that the environmental status was either high or good. 
It is difficult to distinguish oil induced ecological alterations in benthic communities from seasonal and other natural variations. However results of cluster analyses and MDS based on macrobenthic species similarity, distinctly segregated the oil impacted monsoon months from the other sampling months (including the monsoon months of 2011). The plots illustrated a gradual variation in the macrobenthic community structure of the other months which could be ascribed to seasonal changes. The plots also indicated that in the immediate months following the spill, macrobenthic community assemblages were influenced by the oil spill along with that of monsoonal forces (i.e. salinity). Such type of synergistic effect of oil pollution and southwest monsoon was observed by Ansari and Ingole (2002) on the intertidal meiobenthic community of Goa after a major oil spill.

Among the specific physico-chemical parameters that may have influenced the macrobenthic biotic structure at Colaba (as per BIOENV), changes in $\mathrm{C}_{\text {org }}$ and $\mathrm{PHc}$-water would be resultant of the oil spill and other anthropogenic activities (port activities, indiscriminate release of sewage) considering the setting of the study area. Variations in the other three parameters i.e. water temperature, SS and silt \% were mostly due to natural perturbations. The role of $\mathrm{C}_{\text {org }}$ and sediment texture in determining benthic community structure is well known (Akoumianaki and Nicolaidou 2007; Kodama et al. 2012). Sediment texture has a major role in the distribution of petroleum hydrocarbons and sediments having silt or clay percentage contain more petroleum hydrocarbon (Sengupta et al. 1993). Sediments at sampling sites were predominantly sandy. Correlation analyses show significant inverse correlation of sand\% with PHc-sediment. Therefore sandy sediment texture could also be one of the reasons for modest impact of oil spill. Mandal and Harkantra (2013), while studying the macrobenthos of the Mumbai Port area, too have observed that water temperature, SS and sediment texture were important environmental variables defining the benthic communities of the Mumbai coast. Besides $\mathrm{C}_{\text {org }}$, PHc-water is the other anthropogenic factor determining the macrobenthic community structure in the study area. Lower macrobenthic abundances and species diversity associated with higher levels of sediment hydrocarbons were reported by Seng et al. (1987). In the present study, significant negative relationship of PHc-water levels with macrobenthic species richness indicated that hydrocarbons influenced the macrobenthic community structure. In a similar post oil spill ( $M V$ Pacific Adventurer) study of a subtropical rocky shore, Stevens et al. (2012) observed that oiling had impacted macrobenthic community structure. 
It is generally agreed that the severity of oil related impacts depends on characteristics of the affected area, tide and weather conditions during the episode besides the type and volume of oil spilled (Parker and Wiens 2005). Rocky shores are generally less vulnerable to oil spill damage than many other aquatic habitats due to their hard substratum, generally open nature and high energy conditions (Gundlach and Hayes 1978; IUCN 1983). Being remarkably resilient, recovery can occur rapidly in these zones due to recruitment from unaffected areas (Kingston 2002; Thompson et al. 2002). In a review by Sell et al. (1995), 23 of 27 oiled rocky shores studied recovered within three years. Stevens et al. (2012) have reported the persistence of oil up to five months on subtropical rocky shores of eastern Australia while Jones et al. (1998) recorded that oil cover on rocks disappeared three years after the 1991 Gulf war oil spill. The rocky shore in the present study being exposed to wave action typical of the monsoon season was cleansed of the oil slicks by prevalent physical processes. Absence of visible oiling on the rocks and low PHc-water values after September 2010 indicated that the oil did not persist long in the area.

In tropical climates oil breaks down rapidly in the higher ambient temperatures and therefore weathering is assumed to be faster as compared to higher latitudes (Stevens et al. 2012). It is also expected that recolonisation and growth of organisms may be faster in tropical climates. Poorly populated zones may be re-populated by marine biota through either immigration or larval settlement once the area is devoid of the oil slick. Therefore the overall long-term effect of an oil spill may be less harmful in tropical areas than in temperate areas. As per Southward et al. (1982), macrobenthic communities of exposed shores already living under stress may demonstrate small initial impacts after an oil spill following it up with a relatively quick recovery. Thus recovery after oil spill is known to be rapid on exposed rocky shores (Teal and Howarth 1984; Kingston 2002). This seems to be the case in the present study. The absence of observed mortality of resident macrobenthos as evidenced by mobile organisms can be attributed to the resilience of the rocky shore communities facilitated by their natural adaptation to strenuous environs (Hir and Hily 2002).

Oil spills provide an opportunity to study the impact of this pollutant on biota residing on various types of substrata which can add fresh perspective to our existing information. The present study concludes that the oil spill resulted in a temporary elevation of $\mathrm{PHc}$ in water and $\mathrm{C}_{\text {org }}$ levels which stabilized rapidly to prevailing background levels at Colaba. The spill had briefly affected the biotic community structure of the area during the initial months, though the BOPA index method indicated that there was no deterioration of ecological quality status due to the Chitra oil spill. The effect of the oil 
spill on the macrobenthos was too short to create any long term impact on the biota of the intertidal pools. The probable reasons for minimal damage caused are a) rocky exposed nature of the study terrain along with sandy sediment b) warm temperatures of the tropical beach c) monsoonal wave action d) moderate quantity of fuel oil spilled (800 t). Year long observations on macrobenthic communities indicated that the Chitra oil spill did not result in a major ecological catastrophe for the species rich rocky shore communities of the Colaba coast as was expected by many ecologists and marine biologists. However, to have concrete judgment on the complete ecological consequences of an oil spill, it is imperative to have similar studies on other ecosystems such as mangrove, corals etc which were outside the purview of this study.

\section{Acknowledgements}

Funding for this work was provided by the Maharashtra Pollution Control Board (MPCB). We thank Dr. Gajbhiye, Scientist-in-charge Regional Centre, CSIR-NIO for facilitating the study.

\section{References}

Agard, J.B., J. Gobin, and R.M. Warwick. 1993. Analysis of marine macrobenthic community structure in relation to pollution, natural oil seepage and seasonal distribution in a tropical environment (Trinidad, West Indies). Marine Ecology Progress Series 92: 233-243.

Akoumianaki, I., and A. Nicolaidou. 2007. Spatial variability and dynamics of macrobenthos in a Mediterranean delta front area: The role of physical processes. Journal of Sea Research 57: 47-64.

Ansari, Z.A., and B.S. Ingole. 2002. Effect of an oil spill from MV Sea Transporter on intertidal meiofauna at Goa, India. Marine Pollution Bulletin 44: 396-402.

Buchanan, J.B. 1984. Sediment analysis. In: Methods for study of marine benthos (second edition) Holme NA and Mc Intyre AD) Blackwell Scientific publications, Oxford and Edinburgh, 1- 65.

Chouksey, M.K., A.N. Kadam, and M.D. Zingde. 2004. Petroleum hydrocarbon residues in the marine environment of Bassein-Mumbai. Marine Pollution Bulletin 49: 637-647.

Clarke, K.R., and R.N. Gorley. 2006. PRIMER V6: User Manual/Tutorial. PRIMER-E Ltd, Plymouth.

Crowe, T.P., R.C. Thompson, S. Bray, and S.J. Hawkins. 2000. Impacts of anthropogenic stress on rocky intertidal communities. Journal of Aquatic Ecosystem Stress and Recovery 7: 273-297.

De-la-Ossa-Carretero, J.A. and J.C. Dauvin. 2010. A Comparison of Two Biotic Indices, AMBI and BOPA/BO2A, for assessing the Ecological Quality Status (EcoQS) of Benthic Macro- invertebrates. Transitional Waters Bulletin 4:12-24. 
Díaz-Castañeda, V., and L.H. Harris. 2004. Biodiversity and structure of the polychaete fauna from soft bottoms of Bahia Todos Santos, Baja California, Mexico, Deep Sea Research Pt II 51: 827-847.

Dauvin, J.C., and T. Ruellet. 2007. Polychaete/amphipod ratio revisited. Marine Pollution Bulletin 55: 215-224.

Dauvin, J.C., G. Bellan, and D. Bellan-Santini. 2010. Benthic indicators: from subjectivity to objectivity-where is the line? Marine Pollution Bulletin 60: 947-953.

Datta, S.N., S.K. Chakraborty, A.K. Jaiswar, and G. Ziauddin. 2010. A comparative study on intertidal faunal biodiversity of selected beaches of Mumbai coast. Journal of Environmental Biology 31: 981986.

Dhargalkar, V.K., and D.S. Komarpant. 2003. Impact of sewage on the distribution, abundance and community structure of rocky intertidal macroalgae of the Colaba coast, Mumbai, India. Seaweed Research and Utilisation 25: 27-36.

Dhargalkar, V.K., A.G. Untawale, and T.G. Jagtap. 2001. Marine macroalgal diversity along the Maharashtra coast: Past and present status. Indian Journal of Marine Sciences 30: 18-24.

Edgar, G.J., L. Kerrison, S.A. Shepherd, and M.V. Toral-Granda. 2003. Impacts of the Jessica oil spill on intertidal and shallow subtidal plants and animals. Marine Pollution Bulletin 47: 276-283.

Gesteira, G.J.L., and J.C. Dauvin. 2000. Amphipods are good bioindicators of the impact of oil-spills on soft-bottom macrobenthic communities. Marine Pollution Bulletin 40: 1017-1027.

Gesteira, G.J.L., and J.C. Dauvin. 2005. Impact of the Aegean Sea oil spill on the subtidal fine sand macrobenthic community of the Ares-Bentanzos Ria (Northwest Spain). Marine Environmental Research 60: 289-316.

Gouveia, A.D., and P.G. Kurup. 1977. Probable movement of a hypothetical oil patch from the Bombay High region. Indian Journal of Marine Sciences 6: 118-121.

Grasshoff, K., M. Ehrhardt, and K. Kremling. 1999. Methods of seawater analysis (Verlag Chemie), 1419.

Guidetti, P., M. Modena, G.L. Mesa, and M. Vacchi. 2000. Composition, abundance and stratification of macrobenthos in the marine area impacted by tar aggregates derived from the Haven Oil spill. Marine Pollution Bulletin 40: 1161-1166.

Gundlach, E.R., and M.O. Hayes. 1978. Vulnerability of coastal environments to oil spill impacts. Marine Technology Society Journal 12: 18-27.

Gupta, I., S. Dhage, and R. Kumar. 2009. Study of variations in water quality of Mumbai coast through multivariate analysis techniques. Indian Journal of Marine Sciences 38: 170-177.

Hir, M.L., and C. Hily. 2002. First observations in a high rocky-shore community after the Erika Oil spill (December 1999, Brittany, France). Marine Pollution Bulletin 44: 1243-1252. 
Ingole, B., S. Sivadas, R. Goltekar, S. Clemente, M. Nanajkar, R. Sawant, C. D'Silva, A. Sarkar, and Z. Ansari. 2006. Ecotoxicological effect of grounded MV River Princess on the intertidal benthic organisms off Goa. Environment International 32: 284 - 291.

Ingole, S.A., A.N. Kadam, M.S. Mayadeo, and P.M. Dhadke. 1995. Petroleum hydrocarbons in intertidal ecosystem along the Bombay coast. Indian Journal of Marine Sciences 24: 116-118.

IOC-UNESCO. 1982. The determination of petroleum hydrocarbons in sediments. Manuals and Guides No. 11, 1-38.

IOC-UNESCO. 1984. Manual for monitoring oil and dissolved dispersed petroleum hydrocarbons in marine waters and on beaches. Manual and Guides No. 13, 1-35.

Islam, M.S., and M. Tanaka. 2004. Impacts of pollution on coastal and marine ecosystems including coastal and marine fisheries and approach for management: a review and synthesis. Marine Pollution Bulletin 48: 624-649.

IUCN. 1983. Impact of oil pollution on living resources. J. M. Baker (Chairman), Working Group on Oil Pollution of the IUCN Commission on ecology in Co-operation with the World Wildlife Fund. Commission on Ecology Papers No. 4. International Union for Conservation of Nature and Natural Resources.

Jones, D.A., J. Plaza, I. Watt, and M.A. Sanei. 1998. Long-term (1991-1995) monitoring of the intertidal biota of Saudi Arabia after the 1991 Gulf war oil spill. Marine Pollution Bulletin 36: 472-489.

Joydas, T.V., M.A. Qurban, A. Al-Suwailem, P.K. Krishnakumar, Z. Nazeer, and N. A. Cali. 2012. Macrobenthic community structure in the northern Saudi waters of the Gulf, 14 years after the 1991 oil spill. Marine Pollution Bulletin 64: 325-335.

Junoy, J., C. Castellanos, J.M. Viéitez, M.R. de la Huz, and M. Lastra. 2005. The macroinfauna of the Galician sandy beaches (NW Spain) affected by the Prestige oil-spill. Marine Pollution Bulletin 50, 526-536.

Kamble, S.R., and R. Vijay. 2011. Assessment of water quality using cluster analysis in coastal region of Mumbai, India. Environmental Monitoring Assessment 178: 321-332.

Kingston, P.F. 2002. Long-term environmental impact of oil spills. Spill Science \& Technology Bulletin 7: 53-61.

Kodama, K., J. Lee, M. Oyama, H. Shiraishi, and T. Horiguchi. 2012. Disturbance of benthic macrofauna in relation to hypoxia and organic enrichment in a eutrophic coastal bay. Marine Environmental Research 76: 80-89.

Labrune, C., J.M. Amouroux, R. Sarda, E. Dutrieux, S. Thorin, R. Rosenberg, and A. Grémare. 2006. Characterization of the ecological quality of the coastal Gulf of Lions (NW Mediterranean). A comparative approach based on three biotic indices. Marine Pollution Bulletin 52: 34-47. 
Lopes, C.F., J.C.C. Milanelli, V.A. Prosperi, E. Zanardi, and A.C. Truzzi. 1997. Coastal monitoring program of São Sebastião Channel: Assessing the effects of 'Tebar V' oil spill on rocky shore populations. Marine Pollution Bulletin 34: 923-927.

Lv, Y., W. Zhang, Y. Gao, S. Ning, and B. Yang. 2011. Preliminary study on responses of marine nematode community to crude oil contamination in intertidal zone of Bathing Beach, Dalian. Marine Pollution Bulletin 62: 2700-2706.

Mandal, S., and S.N. Harkantra. 2013. Changes in the soft-bottom macrobenthic diversity and community structure from the ports of Mumbai, India. Environmental Monitoring and Assessment 185: 653-672.

NAS. 1985. Oil in the Sea: Inputs, fates and effects. National Academy of Sciences Press, Washington, DC.

Nikitik, C.C.S., and A.W. Robinson. 2003. Patterns in benthic populations in the Milford Haven waterway following the 'Sea Empress' oil spill with special reference to amphipods. Marine Pollution Bulletin 46: 1125-1141.

NIO. 2011. Impact of accidental spillage of spillage of oil and hazardous chemicals in Mumbai Bay, subsequent to ship collision on 7 August 2010, on marine ecology. Maharashtra Pollution Control Board.

Nelson, W.G. 1982. Experimental studies of oil pollution on the rocky intertidal community of a Norwegian Fjord. Journal of Experimental Marine Biology and Ecology 65: 121-138.

Parker, K.R., and J.A. Wiens. 2005. Assessing recovery following environmental accidents: environmental variation, ecological assumptions and strategies. Ecological Applications 15: 2037-2051.

Peso-Aguiar, M.C., D.H. Smith, R.C.F. Assis, L.M. Santa-Isabel, S. Peixinho, E.P. Gouveia, T.C.A. Almeida, W.S. Andrade, C.R.G. Carqueija, F. Kelmo, G. Carrozzo, C.V. Rodrigues,

G.C. Carvalho, A.C.S. Jesus. 2000. Effects of petroleum and its derivatives in benthic communities at Baía de Todos os Santos/Todos os Santos bay, Bahia, Brazil. Aquatic Ecosystem Health and Management 3: 459-470.

Sell, D., L. Conway, T. Clark, G.B. Picken, J.M. Baker, G.M. Dunnet, A.D. McIntyre, and R.B. Clark. 1995. Scientific criteria to optimize oil spill cleanup. In: Proceedings, 1995 International Oil Spill Conference. American Petroleum Institute, Washington DC, 595-610.

Seng, L.T., L.Y. Kwong, H.S. Chye, K.K. Huat, K.S. Pheng, S. Hanapi, W.T. Meng, R.S. Legore, W.D. Ligny, and G.T. Tan. 1987. Effects of a crude oil terminal on tropical benthic communities in Brunei. Marine Pollution Bulletin 18: 31-35.

Sengupta, R., S.P. Fondekar, and R. Alagarsamy. 1993. State of oil pollution in the northern Arabian Sea after the 1991 Gulf oil spill. Marine Pollution Bulletin 27: 85-91. 
Shriadah, M.M.A. 1998. Impacts of an oil spill on the marine environment of the United Arab Emirates along the Gulf of Oman. Marine Pollution Bulletin 36: 876-879.

Sivadas, S., B. Ingole, M. Nanajkar. 2011. Temporal variability of macrofauna from a disturbed habitat in Zuari estuary, west coast of India. Environmental Monitoring Assessment 173: 65-78.

Sivadas, S., A. Gregory, and B. Ingole. 2008. How vulnerable is Indian coast to oil spills? Impact of MV Ocean Seraya oil spill. Current Science 95: 504-512.

Southward, A.J., Baroness White, S.L. Vader, J.S. Gray, and D.J. Crisp. 1982. An ecologist's view of the implications of the observed physiological and biochemical effects of petroleum compounds on marine organisms and ecosystems. Philosophical Transactions of the Royal Society of London B297: 241-255.

Stevens, T., A. Boden, J.M. Arthur, T.A. Schlacher, D. Rissik, and S. Atkinson. 2012. Initial effects of a moderate-sized oil spill on benthic assemblage structure of a subtropical rocky shore. Estuarine Coastal and Shelf Science 109: 107-115.

Teal, J.M., and R.W. Howarth. 1984. Oil Spill Studies: A Review of Ecological Effects. Environmental Management 8: 27-44.

Thompson, R.C., T.P. Crowe, and S.J. Hawkins. 2002. Rocky intertidal communities: past changes, present status and predictions for the next 25 years. Environmental Conservation 29: 168-191.

Vincent, C., H. Heinrich, A. Edwards, K. Nygaard, and J. Haythornthwaite. 2002. Guidance on typology, references conditions and classification systems for transitional and coastal waters, CIS Working Group 2.4 (Coast) Common Implementation Strategy of the Water Framework Directive, European Commission, pp. 119

Walkey, A., and I.A. Black. 1934. An examination of the Degtjareff method for determining soil organic matter and a proposed modification of the chromic acid titration method. Soil Science 37: 28- 30.

Wafar, M., K. Venkataraman, B. Ingole, S.A. Khan, and P. Lokabharathi. 2011. State of Knowledge of Coastal and Marine Biodiversity of Indian Ocean Countries. PLoS ONE 6: e14613. doi:10.1371/journal.pone.0014613.

www.imd.gov.in accessed on 2.12.2012.

Yamamoto, T., M. Nakaoka, T. Komatsu, H. Kawai, Marine Life Research Group of Takeno, K.

Ohwada, 2003. Impacts by heavy-oil spill from the Russian tanker Nakhodka on intertidal ecosystems: recovery of animal community. Marine Pollution Bulletin 47: 91-98.

Zenetos, A., J. Hatzianestis, M. Lantzouni, M. Simboura, E. Sklivagou, and G. Arvanitakis. 2004. The Eurobulker oil spill: mid-term changes of some ecosystem indicators. Marine Pollution Bulletin 48: 122131. 


\section{List of figures}

Fig.1 Location of the study site at Colaba, west coast of India

Fig.2 Temporal variations in hydro-sedimentological parameters during August 2010 to October 2011. Water temperature (A), pH (B), SS (C), salinity (D), DO (E), $\mathrm{PO}_{4}{ }^{3-}-\mathrm{P}(\mathrm{F}), \mathrm{NO}_{3}{ }^{-}-\mathrm{N}(\mathrm{G}), \mathrm{NH}_{4}{ }^{+}-\mathrm{N}(\mathrm{H})$, PHc-water (I), Sand (J), $C_{\text {org }}(\mathrm{K})$, PHc-sediment (L). Shaded region indicates monsoon season

Fig.3 Temporal variations in macrobenthic abundance (A), species richness $d(\mathrm{~B})$, evenness $J^{\prime}(\mathrm{C})$ and species diversity $H^{\prime}$ (D) during August 2010 to October 2011. Shaded region indicates monsoon season

Fig.4 Hierarchical agglomerative clustering of macrobenthic data of Colaba during 2010-2011 with SIMPROF tests $(p=0.05)$.

Fig.5 MDS ordination of macrobenthic abundances for different sampling months (August 2010October 2011). Groups denote the three groups identified by cluster analysis

Fig.6 BOPA index with standard error bars and ecological status of the study area during August 2010 to October 2011 
Table 1: Results of SIMPER analysis of Cluster groups $a, b$ and $c$. Species accounting for cumulative contribution of $\sim 50 \%$ is reported.

Group a \& b

$$
\begin{array}{cccc}
\mathrm{Av}^{\mathrm{a}} \text {.Diss } & \text { Dissimilarity/ } & \text { Contribution } & \text { Cumulative } \\
& \mathrm{SD}^{\mathrm{c}} & \% & \%
\end{array}
$$

Av. Dissimilarity $=66.12$

Melitidae

7.89

4.75

11.94

11.94

Scoloplos uniramus

4.56

1.85

6.9

18.84

Isopoda

3.59

0.96

5.43

24.27

Capitellidae

3.55

0.77

5.38

29.65

Anomura

3.3

Melitidae

2.43

1.18

4.99

34.64

1.1

3.68

38.32

Planaxis sulcatus

1.56

3.48

41.8

Nerita sp.

1.84

1.15

2.79

44.58

Brachyura

1.75

1.23

2.65

47.23

Diopatra sp.

2.67

2.61

49.84

Group a \& c

Av. Dissimilarity $=68.01$

Melitidae

5.62

2.34

8.26

8.26

Prionospio sp.

4.24

1.64

6.24

14.5

Isopoda

4.11

6.04

20.54

Scoloplos uniramus

3.92

1.89

5.77

26.31

Nerita sp.

2.09

5.38

31.69

Planaxis sulcatus

2.94

1.5

4.32

36.01

Melitidae

0.96

4.21

40.23

Nerita oryzarum

1.24

3.69

43.92

Syllis sp.

2.51

1.2

3.69

47.61

Group b \& c

Av.Dissimilarity $=59.80$

Capitellidae $\quad 4.04$

Scoloplos uniramus $\quad 3.49$

Anomura

3.47

Melitidae

3.35

1.37

6.75

6.75

1.61

5.84

12.59

1.5

5.8

18.39

1.49

5.6

23.99

Nerita sp.

2.76

1.55

4.61

28.6

Prionospio sp.

2.72

1.64

4.55

33.15

Syllis sp.

1.53

3.76

36.92

Nerita oryzarum

2.25

1.33

3.17

40.09

1.75

0.96

2.92

43.01

Brachyura

1.7

2.18

2.83

45.84

Spiophanes bombyx

1.6

1.04

2.68

48.52

\footnotetext{
a average

${ }^{\mathrm{b}}$ contribution of the $i$ th genera to the total dissimilarity

${ }^{c}$ SD-standard deviation.
} 
Table 2: Results of BIO-ENV analyses for Colaba intertidal zone. Only the best correlation for each category is shown. Variables marked in bold indicates overall optimum Spearman correlation $(\rho)$.

\begin{tabular}{|c|c|c|}
\hline $\begin{array}{l}\text { No. of Variables } \\
\text { correlation }\end{array}$ & Variables & Spearman ( ) \\
\hline 1 & $\mathrm{C}_{\text {org }}^{\mathrm{a}}$ & 0.519 \\
\hline 2 & $\mathrm{C}_{\text {org, }}$ PHc-water ${ }^{\mathrm{b}}$ & 0.612 \\
\hline 3 & $\mathrm{C}_{\text {org }}$, PHc-water, $\mathrm{SS}^{\mathrm{c}}$ & 0.619 \\
\hline 4 & $\mathrm{C}_{\text {org }}, \mathrm{PHc}-$ water,Temp. ${ }^{\mathrm{d}}, \mathrm{SS}$ & 0.616 \\
\hline 5 & C $_{\text {org,PHc-water,Temp., SS, Silt }}$ & 0.624 \\
\hline 6 & $\mathrm{C}_{\text {org, }}$ PHc-water,Temp., SS, Silt, PHc-sediment & 0.619 \\
\hline
\end{tabular}

\footnotetext{
${ }^{\text {a }}$ Organic carbon

${ }^{\mathrm{b}}$ Petroleum hydrocarbons in water

c Suspended solids

${ }^{\mathrm{d}}$ Water temperature;
} 
Table 3: Average values of the biological and environmental parameters selected by BIOENV in each of the three groups formed by the cluster analyses/ multidimensional scaling ordination.

\begin{tabular}{|c|c|c|c|}
\hline Parameter & Group $a(\mathrm{n}=2)$ & Group $b(\mathrm{n}=5)$ & Group $c(n=8)$ \\
\hline $\mathrm{C}_{\text {org }}(\%)^{\mathrm{a}}$ & $1.5 \pm 1.1$ & $0.7 \pm 0.3$ & $0.2 \pm 0.1$ \\
\hline PHc-water $\left(\mu g ~^{-1}\right)^{b}$ & $934.1 \pm 1260.5$ & $19.1 \pm 17.2$ & $12.9 \pm 6.1$ \\
\hline $\mathrm{SS}\left(\mathrm{mg} \mathrm{l}^{-1}\right)^{\mathrm{c}}$ & $131.5 \pm 65.8$ & $103.4 \pm 163.1$ & $30 \pm 12.8$ \\
\hline Water temperature $\left({ }^{\circ} \mathrm{C}\right)$ & $29.3 \pm 1.1$ & $26.8 \pm 2.2$ & $28.8 \pm 0.9$ \\
\hline Silt (\%) & $0.2 \pm 0$ & $2.6 \pm 3.2$ & $1.9 \pm 1.6$ \\
\hline$H^{\prime}\left(\log _{2}\right)$ & $3.0 \pm 0.3$ & $3.2 \pm 0.2$ & $3.3 \pm 0.3$ \\
\hline$d$ & $2.1 \pm 0.9$ & $2.8 \pm 0.6$ & $2.6 \pm 0.4$ \\
\hline$J^{\prime}$ & $0.8 \pm 0.1$ & $0.7 \pm 0.1$ & $0.8 \pm 0.1$ \\
\hline No.of groups & $16 \pm 7.8$ & $22 \pm 5.7$ & $19 \pm 2.9$ \\
\hline Total & $863 \pm 644.2$ & $2124 \pm 1168.1$ & $954 \pm 445.0$ \\
\hline \multicolumn{4}{|l|}{ Density (ind. $\mathrm{m}^{-2}$ ) } \\
\hline Polychaeta & 91 & 878 & 524 \\
\hline Crustacea & 450 & 897 & 308 \\
\hline Mollusca & 313 & 318 & 116 \\
\hline Echinodermata & 6 & 4 & 4 \\
\hline Others & 3 & 27 & 2 \\
\hline \multirow[t]{7}{*}{ Major discriminating taxa } & Melitidae (94) & Melitidae (458) & Melitidae (139) \\
\hline & Scoloplos uniramus(32) & Scoloplos uniramus (341) & Scoloplos uniramus(213) \\
\hline & Isopoda (191) & Isopoda (82) & Isopoda (1) \\
\hline & Capitellidae (0) & Capitellidae (310) & Capitellidae (49) \\
\hline & Prionospio sp.(0) & Prionospio sp.(9) & Prionospio sp.(74) \\
\hline & Anomura (3) & Anomura (105) & Anomura (0) \\
\hline & Nerita sp.(116) & Nerita sp.(98) & Nerita sp.(6) \\
\hline
\end{tabular}

a Organic carbon

${ }^{\mathrm{b}}$ Petroleum hydrocarbons in water

c Suspended solids 


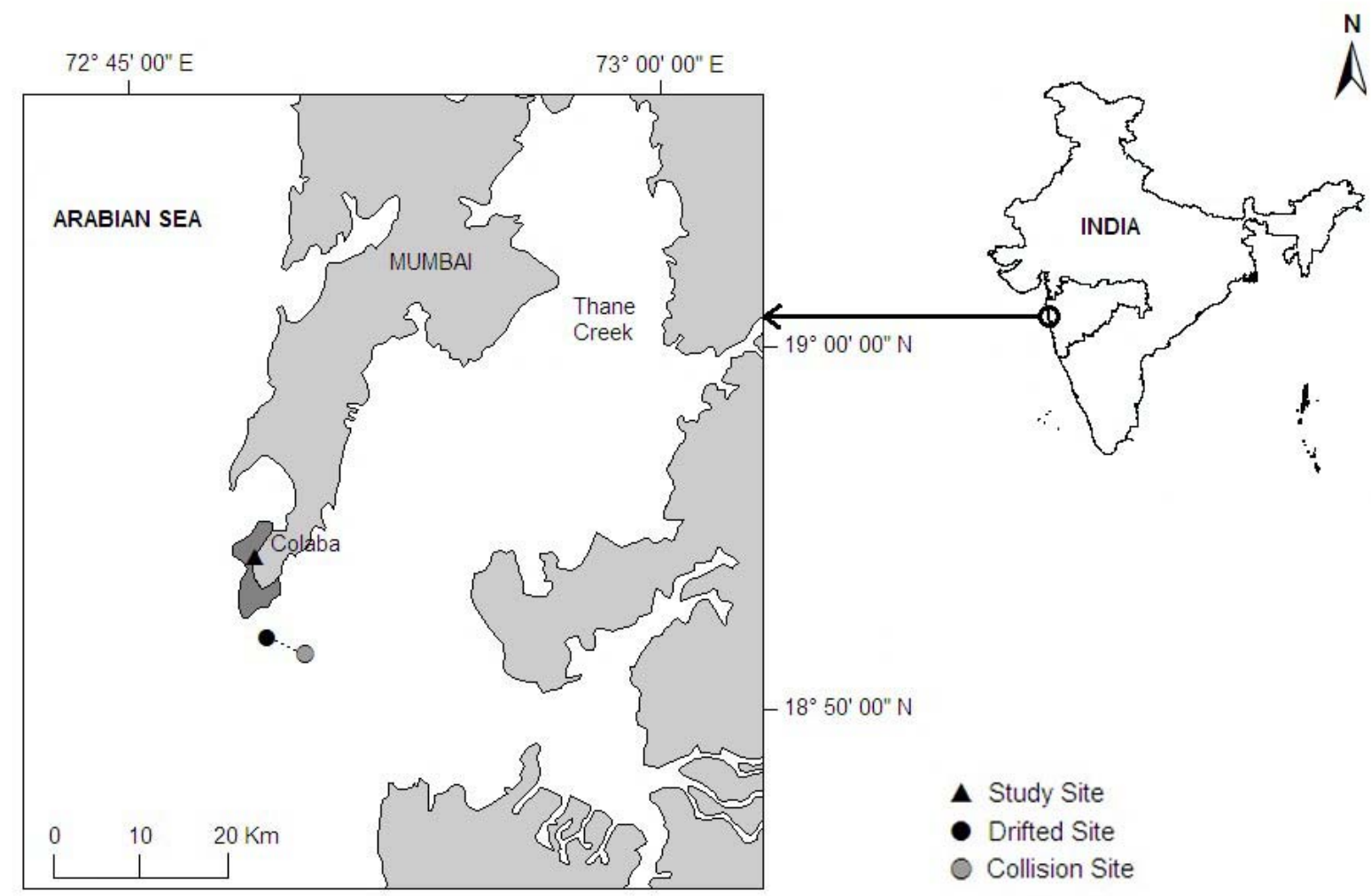

Fig. 1 Location of the study site at Colaba, west coast of India 

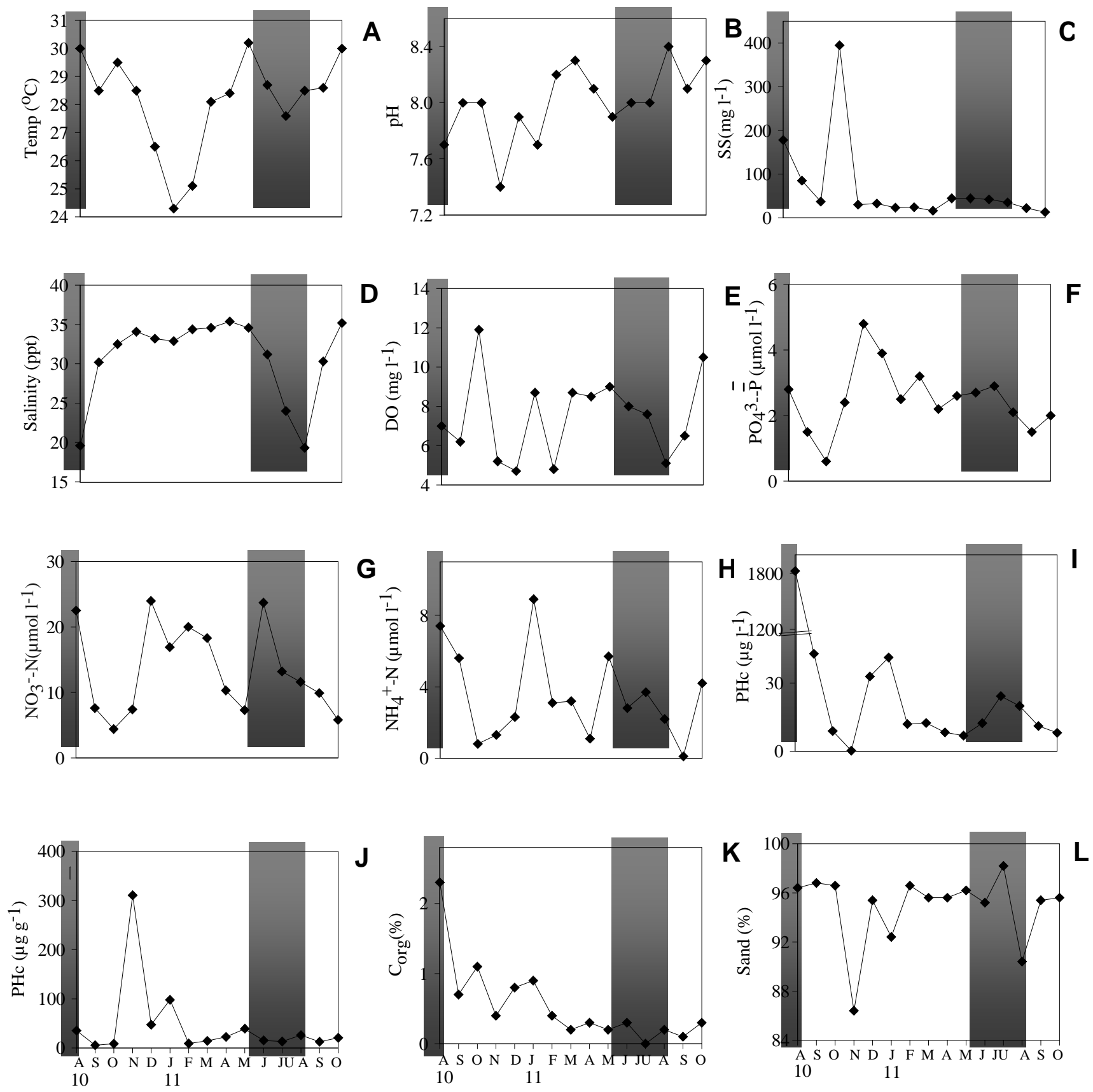

Fig. 2 Temporal variations in hydro-sedimentological parameters during August 2010 to October 2011. Water temperature (A), $\mathrm{pH}(\mathrm{B}), \mathrm{SS}(\mathrm{C})$, salinity (D), DO (E), $\mathrm{PO}_{4}{ }^{3-}-\mathrm{P}(\mathrm{F}), \mathrm{NO}_{3}{ }^{-}-\mathrm{N}(\mathrm{G}), \mathrm{NH}_{4}{ }^{+}-\mathrm{N}(\mathrm{H})$, PHc-water (I), Sand (J), $C_{\text {org }}(\mathrm{K})$, PHc-sediment (L). Shaded region indicates monsoon season 


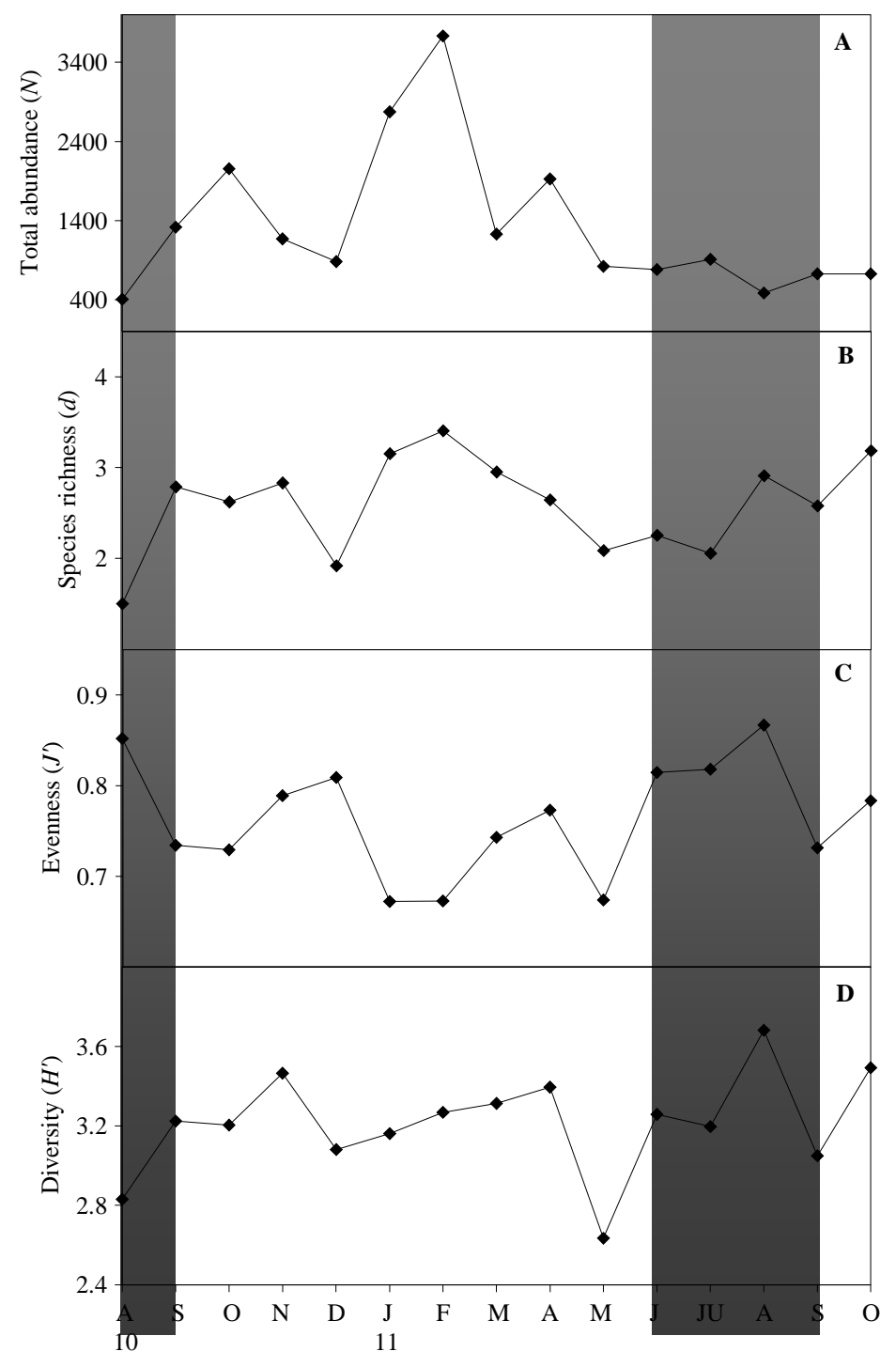

Month

Fig. 3 Temporal variations in macrobenthic abundance (A), species richness $d$ (B), evenness $J$ ' (C) and species diversity $H^{\prime}$ (D) during August 2010 to October 2011. Shaded region indicates monsoon season 


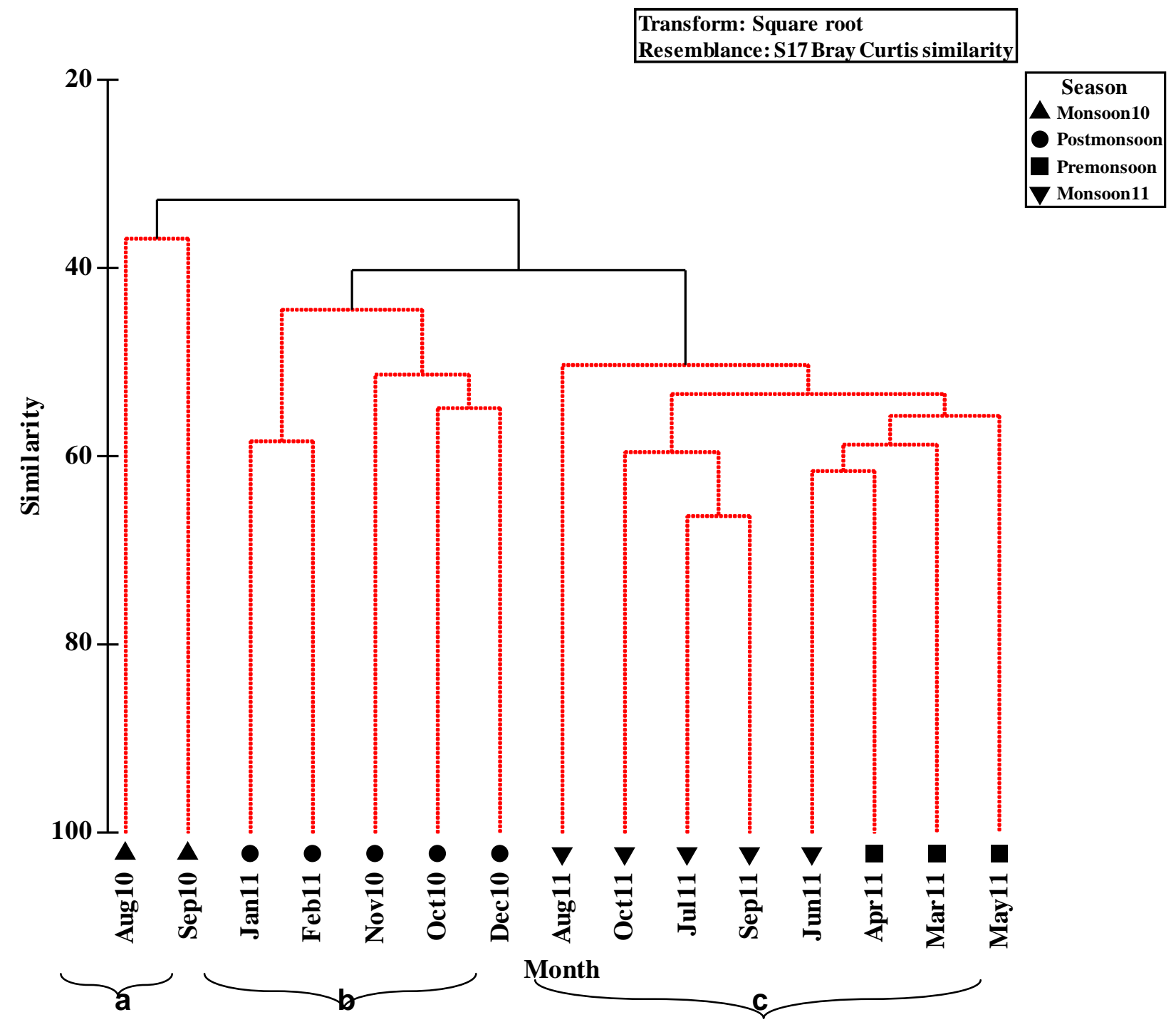

Fig. 4 Hierarchical agglomerative clustering of macrobenthic data of Colaba during 2010-2011 with SIMPROF tests $(p=0.05)$. 


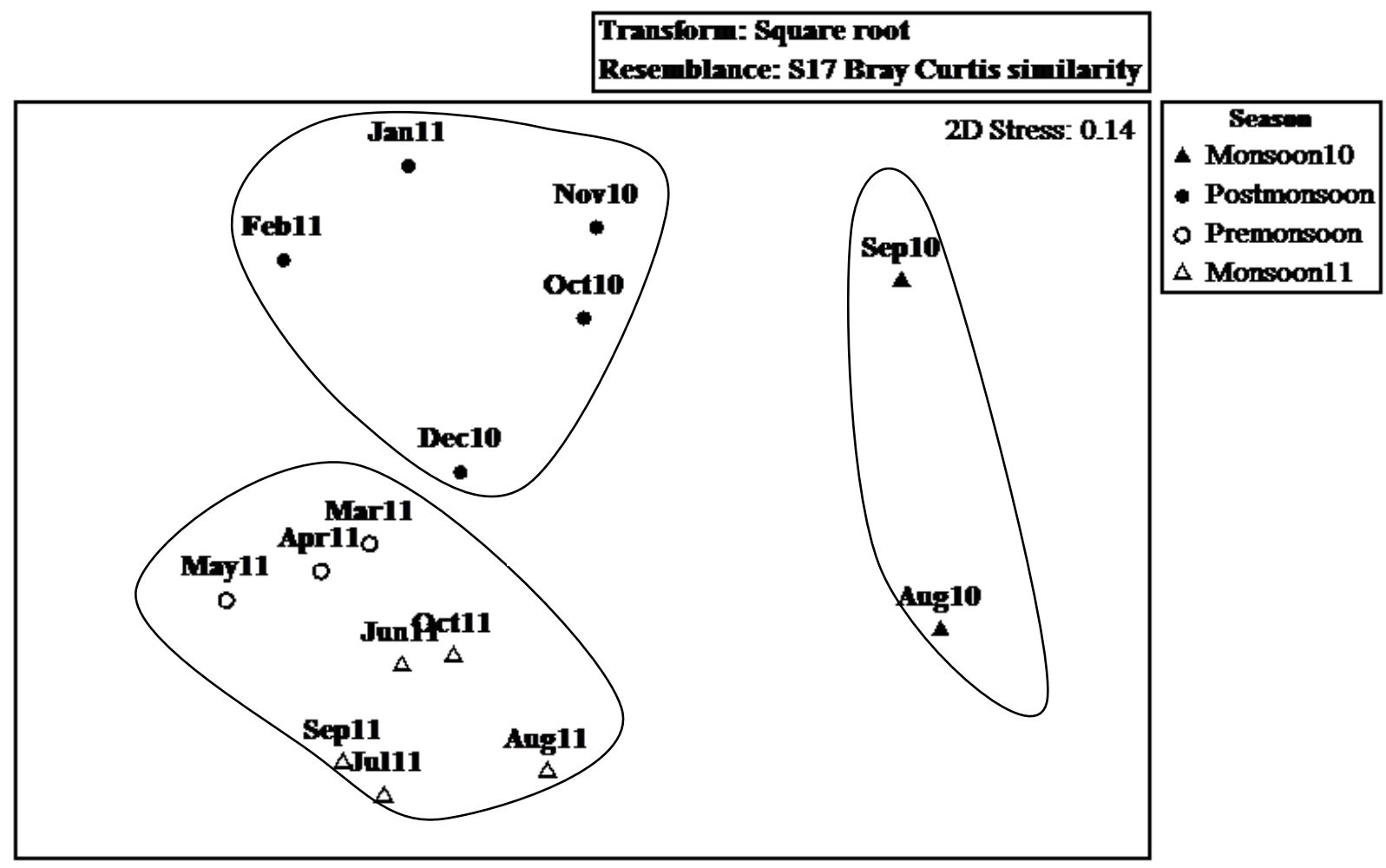

Fig.5 MDS ordination of macrobenthic abundances for different sampling months (August 2010October 2011). Groups denote the three groups identified by cluster analysis 


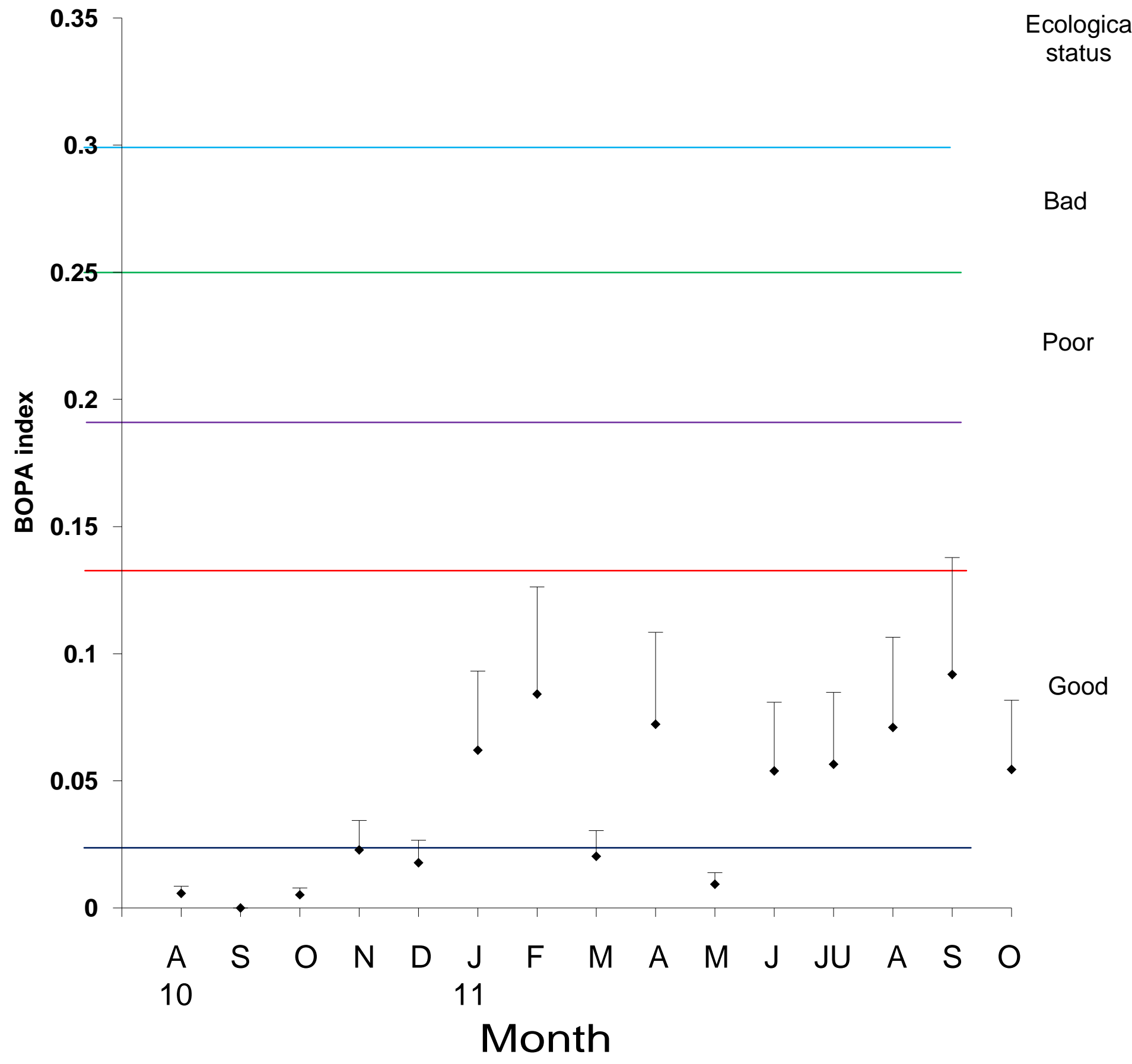

Fig. 6 BOPA index with standard error bars and ecological status of the study area during August 2010 to October 2011 